\title{
UNCERTAINTY AND THE DISAPPEARANCE OF INTERNATIONAL CREDIT
}

\author{
Joshua Aizenman \\ Nancy Marion \\ Working Paper 7389 \\ http://www.nber.org/papers/w7389 \\ NATIONAL BUREAU OF ECONOMIC RESEARCH \\ 1050 Massachusetts Avenue \\ Cambridge, MA 02138 \\ October 1999
}

This paper was presented at the conference on Financial Crises in Emerging Markets sponsored by the Center for Pacific Basin Monetary and Economic Studies of the Federal Reserve Bank of San Francisco, September 23-24, 1999. We wish to thank Mark Spiegel, our discussant, and other participants at the conference for their comments. We wish to thank Changyong Rhee and officials at the Ministry of Finance and Economy of Korea for help in obtaining data. Any errors are ours. The views expressed herein are those of the authors and not necessarily those of the National Bureau of Economic Research.

(c) 1999 by Joshua Aizenman and Nancy Marion. All rights reserved. Short sections of text, not to exceed two paragraphs, may be quoted without explicit permission provided that full credit, including $(\mathbb{C}$ notice, is given to the source. 
Uncertainty and the Disappearance

of International Credit

Joshua Aizenman and Nancy Marion

NBER Working Paper No. 7389

October 1999

JEL No. F2, F3

\section{ABSTRACT}

We show that increased uncertainty about the size of an emerging market's external debt has a nonlinear and potentially large adverse effect on the supply of international credit offered to them. We also show that if international creditors are first-order risk averse, attaching greater weight to utility derived from bad outcomes than from good ones, a moderate increase in uncertainty about debt overhang-or about other relevant factors affecting repayment prospects-- can cause the supply of credit to dry up completely. We therefore offer one possible explanation for why emerging markets may find themselves suddenly cut off from international capital markets.

Joshua Aizenman

Department of Economics

Dartmouth College

Hanover, NH 03755

and NBER

joshua.aizenman@dartmouth.edu
Nancy P. Marion

Department of Economics

Dartmouth College

Hanover, NH 03755

nancy.p.marion@dartmouth.edu 


\section{Introduction}

In this paper, we examine how increased uncertainty about an emerging market's debt overhang might affect the willingness of foreign investors to supply new international credit. We show that increased uncertainty about the debt overhang has a nonlinear and potentially large adverse effect on the supply of international credit. As a result, it can contribute to the liquidity shortage often experienced by emerging markets during a crisis. We also show that if international creditors have preferences characterized by first-order risk aversion, a moderate increase in uncertainty about debt overhang — or about other relevant factors affecting repayment prospects- can cause the supply of credit to dry up completely. We therefore offer one possible explanation for why emerging markets may find themselves suddenly cut off from international capital markets.

We begin by describing events that contributed to increased uncertainty about the debt overhang in two of the Asian economies hit hard by the financial crisis in 1997-Thailand and South Korea. We then compare reported external debt levels before the crisis with higher figures uncovered once the crisis began. We suggest that external debt levels for these two countries turned out to be much higher than what was reasonably foreseen. Surprised by the size of the upward adjustments, investors likely attached greater uncertainty to the size of the debt as well.

Previous investigations of debt overhang have generally focused on the level of outstanding debt and its impact on the economy. We use a modified model of sovereign risk to analyze the impact of greater uncertainty about the debt level. We show that more uncertainty reduces the supply of international credit when there is a chance of default. More uncertainty also magnifies the effect of news about the level of outstanding debt. We also observe that if we abandon the capital asset pricing model as a way of explaining portfolio choice and instead rely 
on a specification where agents attach more weight to utility from "bad' outcomes than from "good" outcomes, investors will require a substantial risk premium to diversify internationally. Further, a moderate increase in the perceived risk of lending can induce investors to shift out of emerging-market assets completely.

The paper is organizes as follows. Section 2 illustrates the build-up of external debt levels in Thailand and South Korea and makes a case for increased uncertainty about the debt. Section 3 uses a model to analyze the effects of increased uncertainty about debt overhang on the supply of international credit offered emerging markets. Section 4 examines how greater uncertainty may lead risk-averse investors to shift out of emerging-market assets entirely, even if those assets offer a risk premium. Section 5 concludes.

\section{External debt levels in Thailand and South Korea}

Figure 1 shows the growth of Thailand's external debt over the 1990s. In 1990, the Bank of Thailand reported an external debt of US\$25.06 billion. By the end of 1995 , this figure had grown $172 \%$ to $\$ 68.13$ billion. At the end of 1996 , this figure was $\$ 79.85$ billion, $17 \%$ higher than the previous year. Once the financial crisis for Thailand began on July 2, 1997, the Bank of Thailand reported revised debt figures. Total external debt for 1995 turned out to be $\$ 82.57$ billion, a $21 \%$ upward adjustment over the previously-reported 1995 value, while the figure for 1996 was revised up by $26 \%$, to $\$ 90.54$ billion. Even before the crisis hit, however, there were rumors and press reports about higher debt figures. On May 17, 1997, for example, The Economist reported that Thailand's external debt was probably closer to $\$ 90$ billion, with perhaps $\$ 70$ billion owed by the private sector. 
Figure 2 shows the growth in South Korea's external debt over the same period. The Korean government's original measure of external liabilities followed the World Bank definition and did not include the off-shore borrowing of domestic financial institutions or the liabilities of foreign branches and subsidiaries of domestic financial institutions. The original measure is labeled in Figure 2 as the "old" definition. These are data reported by Korea's Ministry of Finance and Economy before the crisis engulfed the country (before October 25, 1997). Since external liabilities from the excluded entities turned out to be considerable, the Korean government and the IMF agreed to include these liabilities in a new definition of external debt. ${ }^{1}$ Debt figures using the new definition now go back to 1995 and are also shown in Figure 2.

The striking observation about Figure 2 is that Korea's external debt, like Thailand's, turned out to be much higher than what was originally reported. An examination of the 1996 figures illustrates the point. The Financial Times reported on May 7, 1997, just five months before Korea succumbed to the crisis, that the South Korean government had put its 1996 gross external debt (old definition) at $\$ 104.5$ billion. The government later revised the figure upward to $\$ 113.6$ billion (still using the old definition). The figure jumped to $\$ 164.34$ billion under the new definition, about a $60 \%$ increase over what was initially reported by the Financial Times in May.

The discrepancy between the originally-reported and revised September, 1997, estimate was equally dramatic. In December, 1997, investors learned that Korea's total external debt for September was about $\$ 170$ billion when measured by the new definition. More alarming was the revelation that about $60 \%$ of it was short-term in nature. The IMF later stated that "In

\footnotetext{
${ }^{1}$ The liabilities of foreign branches and subsidiaries of domestic enterprises are not included in either definition.
} 
December, ... investors and lenders panicked when they learned that the country's short-term external debt was approximately $\$ 104$ billion---rather than the $\$ 66$ billion originally reported ..." (Adams, et al., 1998, p. 155). ${ }^{2}$ Describing the financial crisis that hit Korea, the OECD reported that "the lack of timely, reliable information on the state of (Korea's) ..... foreign debt added to uncertainty" during this period. (OECD, 1998, p. 31). When Standard and Poor's lowered Korea's sovereign credit rating on December 11 , one reason cited for its actions was the lack of transparency about external debt.

The upward adjustments in external debt figures increased investor pessimism and contributed to the collapse of the international credit market for Thailand, Korea and other emerging markets. The large reversal of international capital flows in the fourth quarter of 1997 has been widely documented (e.g. Adams, 1998). The transformation in institutional structures has also been noted:

"Before the crisis, the typical foreign exchange market was an interbank market with banks willing to take on intraday foreign exchange exposures in order to provide market liquidity and to help match order flows throughout the day. Even when required by regulation to limit overnight foreign exchange exposure, these intraday exposures could be quite large. This type of interbank market totally collapsed during the crisis as banks refused to take intraday open positions (because of the fear that counterparties would not deliver.)......

In domestic money markets, .....as concerns about the solvency of domestic banks increased, many foreign banks would make loans in the domestic currency in the local interbank market only to other foreign banks. Moreover, some of the stronger domestic banks would only deal with the local foreign banks.

\footnotetext{
${ }^{2}$ Park and Rhee (1998) argue that the Korean government made the market more speculative by not confirming or officially announcing these figures.
} 
The structure of equity markets also was transformed when broker dealers that acted as market makers could no longer serve that function because of their inability to obtain bank credit."

(Mathieson, forthcoming.)

We obtain some suggestive evidence on investor beliefs about external debt levels in Thailand by constructing confidence bands around a forecast of debt. To obtain the forecast, we assume that investors believed external debt followed an auto-regressive process. We therefore regress the log of external debt on a constant and its one-period lagged value, using debt levels reported before the financial crisis occurred.

Using quarterly data for the period 90:4 through 95:3, the regression results for Thailand are:

$$
\begin{aligned}
\overline{\mathrm{D}}_{\mathrm{t}}= & 0.2969+0.9767 \overline{\mathrm{D}}_{\mathrm{t}-\mathrm{l}} \\
& (0.2271)(0.0215)
\end{aligned}
$$

where $\bar{D}$ is the logarithm of (US\$ million) total external debt and standard errors of the estimated coefficients are reported in parentheses. The adjusted $\mathrm{R}^{2}$ is 0.99 , the standard error of the regression is 0.0262 and Durbin's h-statistic of 0.12 suggests that serial correlation is not a problem. $^{3}$

Figure 3 illustrates the data on Thailand's external debt reported prior to the crisis as well as the revised figures from $96: 3$ onwards. ${ }^{4}$ In addition, the figure shows the predicted values of

\footnotetext{
${ }^{3}$ For small samples, one cannot reject the hypothesis that log external debt in Thailand follows a random walk. Both the auto-regressive process and the random walk formulation have similar implications for our topic of interest.
}

\footnotetext{
${ }^{4}$ We have not been able to obtain revised quarterly data for $95: 1-96: 2$, although we have revised annual estimates.
} 
Thai external debt for the estimation period based on the auto-regressive process and the $95 \%$ confidence band surrounding that prediction. For the period 95:4 and after, we assume that investors continue to use (1) to predict quarterly debt. However, the confidence bands around the future predictions widen over time to reflect the growing uncertainty about the true value of Thailand's debt. Note that by the second half of 1996, the revised external debt figure is considerably above the upper confidence band.

We repeat the exercise using the initially reported data over 90:4 - 96:4 to estimate (1). As we see in Figure 3A, the revised debt figure is once again above the upper confidence band from at least 1996:3 onwards. Thus Thailand's external debt turned out to be much higher than any reasonable forecast.

For Korea, we do not have quarterly debt data using the old definition, and a forecasting equation that relies on annual data over the 1990-1995 period of financial liberalization gives an unreliable forecast with very wide confidence bands. So we consider instead the inference problem of investors who try to evaluate the magnitude of the surprise generated by the revision of the reported debt data. We suggest that the greater the debt surprise relative to the standard deviation of the debt process, the greater is the reevaluation of the uncertainty about the size of the total debt. Using the conventional yardstick, if the revision in the reported data is greater than two standard deviations of the debt process, we conclude that the size of the revision is more than what could reasonably have been expected if one maintained the old assumption about the volatility of the underlying debt process. These circumstances would lead investors to increase their assessment of the uncertainty regarding the debt.

For example, consider the case where investors learn in late 1997 that the 1996 external debt is higher than previously reported. In order to evaluate the surprise, the investors compare 
the percentage size of the revision of the 1996 debt figure to the standard deviation of the debt process. To obtain the latter, investors use a first-order auto-regressive process (AR-1) to describe the path of the log of the debt in the years 1989-1995 and calculate the standard deviation of the residuals. (The investor takes 1989 as the starting point of the time series of the debt process because a regime switch towards more financial liberalization occurred in the early 1990s.) Investors repeat the procedure for the years 1989-1996 to evaluate the magnitude of the surprise about the revised debt figure for 1997:3.

Figure 4 illustrates the results of this exercise for Korea's total debt and short-term debt. The magnitude of the surprise about the upward revisions in debt figures is substantial. The upward revision in the 1996 total external debt figure exceeds four standard deviations and the revision in the 1997:3 figure is in excess of three standard deviations. The upward revisions in the 1996 and 1997:3 estimates for short-term debt are each about three standard deviations. All of the upward revisions were thus much greater than what could have been reasonably predicted. ${ }^{5}$

We now develop a model that can show how increased uncertainty about the size of an emerging market's external debt can affect the willingness of foreign investors to supply credit.

\footnotetext{
${ }^{5}$ When the same exercise is repeated for Thailand, the upward revisions in the quarterly estimates for 96:3-97:1 are each on the order of 5.5 to 6.5 standard deviations. While we focus on uncertainty about external debt, there was also enormous uncertainty during this period about other factors affecting repayment prospects of the Asian economies, such as the size of their international reserve holdings needed for possible bail-outs, the extent of currency depreciation that raised real debt burdens, and the fall in property values that worsened balance sheets. When we construct a forecast of net liabilities, measured as the difference between external debt and international reserves, the true value of net liabilities exceeded reasonable predictions by an even greater degree than what is reported here.
} 


\section{The Model}

Consider a global economy with high-income countries and emerging-market economies and a two-period planning horizon. Second period output in the emerging markets is:

$$
Y_{2}^{*}=Y^{*}(1+\varepsilon)
$$

Its value is uncertain because emerging markets are subject to a second-period productivity shock $\varepsilon$ whose probability density function $f(\varepsilon)$ lies over the range $-\varepsilon_{0} \leq \varepsilon \leq \varepsilon_{0}$, with $\varepsilon_{0} \geq 0$

Emerging markets may borrow internationally. However, their ability to borrow is constrained by two factors --- the limited enforceability of international contracts and the uncertainty about the size of their debt overhang. The uncertainty about debt overhang can be characterized in a simple way. Suppose the outstanding debt due to be repaid next period can be either high or low with equal probability: ${ }^{6}$

$$
D_{2}=\left\{\begin{array}{llll}
\bar{D}(1+\lambda) & \text { with } & \text { probability } & 0.5 \\
& & & \\
\bar{D}(1-\lambda) & \text { with } & \text { probability } & 0.5
\end{array}\right.
$$

High-income countries must decide on how much new lending they are willing to provide emerging markets. Let $B_{1}^{*}$ represent the aggregate amount of new short-term loans offered emerging markets in period one at a contractual interest rate of $r$. In period two,

${ }^{6}$ The specification in (3) is the simplest way to model uncertainty about debt overhang. The key results of the model hold for other distributions of $\lambda$, such as the uniform or truncated normal. 
emerging markets must repay these loans plus the debt overhang. Emerging markets may end up defaulting, however, if their period two output turns out to be too low or their repayments too high.

Let $S_{2}$ denote the total debt repayment to foreign creditors in period two. In the event of a default, suppose creditors can penalize the borrowing countries by reducing their net output by an amount $\chi Y_{2}^{*}$. The parameter $\chi$ reflects the bargaining power of foreign lenders, where up to a fraction $\chi$ of output can be "confiscated" by lenders through retaliatory trade measures or other actions. ${ }^{7}$ Consequently, the effective ceiling on net resource transfers to creditors is the lesser of either the contractual repayments or the confiscated output:

$$
S_{2}=\min \left[(1+r) B_{1}^{*}+D_{2} ; \chi Y_{2}^{*}\right]
$$

The size of the productivity shock that makes emerging markets indifferent between repaying their loans or defaulting and facing the output penalty is $\varepsilon^{*}$, where:

$$
\varepsilon^{*}=\left\{\begin{array}{l}
\varepsilon_{+}^{*}=\max \left[\frac{(1+r) B_{1}^{*}+\bar{D}(1+\lambda)}{\chi Y^{*}}-1 ;-\varepsilon_{0}\right] \quad \text { if the initial debt is high } \\
\varepsilon_{-}^{*}=\max \left[\frac{(1+r) B_{1}^{*}+\bar{D}(1-\lambda)}{\chi Y^{*}}-1 ;-\varepsilon_{0}\right] \quad \text { if the initial debt is low }
\end{array}\right.
$$

${ }^{7}$ The term $\chi$ is influenced by a host of factors that relate to the integration of markets. See Bulow and Rogoff (1989) for details. 
Because the size of the debt overhang is uncertain, the value of $\varepsilon^{*}$ is contingent on the realized debt overhang.

The intertemporal pattern of net lending and consumption is determined by price-taking agents who maximize their discounted expected utility. Agents in the high-income countries are risk neutral, so their preferences over a two-period planning horizon are characterized by:

$$
V \equiv C_{1}+\frac{C_{2}}{1+\rho}
$$

where $\rho$ is the rate of time preference and coincides with the risk-free interest rate.

Agents in the emerging-market economies have preferences represented by:

$$
V^{*} \equiv u\left(C_{1}^{*}\right)+\frac{u\left(C_{2}^{*}\right)}{1+\rho^{*}} ; \quad u^{\prime}>; \quad u^{\prime \prime} \leq 0
$$

We assume that $\rho^{*}>\rho$ because the real interest rate in emerging markets is substantially above the rate in the high-income group.

The international credit market is characterized by competition among creditor banks. A default by emerging markets requires creditor banks to spend real resources $\mu$ in order to verify the productivity shock and the size of the debt overhang and to enforce the transfer of resources from emerging markets according to (4). ${ }^{8}$

The risk neutrality of lenders implies that they offer an elastic supply of new credit at

\footnotetext{
${ }^{8}$ To simplify, we lump together monitoring and enforcement costs and we ignore the possibility of randomized monitoring. Boyd and Smith (1994) show that random monitoring makes the financial contract more complex without altering first-order welfare effects. See Townsend (1979)
} 
an expected yield equal to their rate of time preference. In the event of default, confiscated output first goes to cover repayment of the old debt, which is considered senior. To simplify exposition, we focus on the case where confiscated output can fully cover the required repayment of old debt. Thus $r$, the interest rate on new credit to emerging markets, is determined by an arbitrage condition that equates the expected yield on new loans to emerging markets to the risk-free return:

$$
0=(1+\rho) B_{1}^{*}-\left\{\begin{array}{l}
0.5\left[\left\{(1+r) B_{1}^{*}+\bar{D}(1+\lambda)\right\} \int_{\varepsilon_{+}^{*}}^{\varepsilon_{0}} f(\varepsilon) d \varepsilon+\int_{-\varepsilon_{0}}^{\varepsilon_{+}^{*}}\left\{\chi Y^{*}(1+\varepsilon)-\mu\right\} f(\varepsilon) d \varepsilon-\bar{D}(1+\lambda)\right]+ \\
0.5\left[\left\{(1+r) B_{1}^{*}+\bar{D}(1-\lambda)\right\} \int_{\varepsilon_{-}^{*}}^{\varepsilon_{0}} f(\varepsilon) d \varepsilon+\int_{-\varepsilon_{0}}^{\varepsilon_{\bar{*}}^{*}}\left\{\chi Y^{*}(1+\varepsilon)-\mu\right\} f(\varepsilon) d \varepsilon-\bar{D}(1-\lambda)\right]
\end{array}\right.
$$

The second term on the right-hand side of (8) evaluates the expected repayment on new loans when there is an equal chance that the debt overhang will turn out to be high or low. For a given realization of debt overhang, the expected repayment is the sum of three components: (i) the return on new loans and repayment of the debt overhang in the absence of default; (ii) the confiscated output in the case of default, less enforcement costs; (iii) minus the repayment of the debt overhang whether or not there is a default.

Using (5), we can rewrite (8) as:

$$
\left.\left.(r-\rho) B_{1}^{*}=0.5 \int_{-\varepsilon_{0}}^{\varepsilon_{+}^{*}}\left\{\chi Y^{*}\left(\varepsilon_{+}^{*}-\varepsilon\right)+\mu\right\} f(\varepsilon) d \varepsilon\right]+0.5 \int_{-\varepsilon_{0}}^{\varepsilon_{-}^{*}}\left\{\chi Y^{*}\left(\varepsilon_{-}^{*}-\varepsilon\right)+\mu\right\} f(\varepsilon) d \varepsilon\right]
$$

for a model where a debt contract with state verification costs is optimal. See Bernanke and 
Note that monitoring and enforcement costs are passed on to borrowers by way of higher borrowing rates.

We now examine how uncertainty about debt overhang affects the supply of new loans that foreign creditors are willing to offer. ${ }^{9}$ Equation (8) defines the supply of international credit facing emerging markets (along with the definitions of $\varepsilon_{+}^{*} ; \varepsilon_{-}^{*}$ ). We denote the right-hand side of (8) by H. Applying the implicit function theorem to (8), the slope of the supply curve is

$$
\frac{d B_{1}^{*}}{d r}=\frac{-H_{r}^{\prime}}{H_{B_{1}^{*}}^{\prime}}
$$

where

$$
\begin{aligned}
& -H_{r}^{\prime}=0.5 B_{1}^{*}\left\{\left[\int_{\varepsilon_{+}^{*}}^{\varepsilon_{0}} f(\varepsilon) d \varepsilon-\frac{\mu}{\chi Y^{*}} f\left(\varepsilon_{+}^{*}\right)\right]+\left[\int_{\varepsilon_{-}^{*}}^{\varepsilon_{0}} f(\varepsilon) d \varepsilon-\frac{\mu}{\chi Y^{*}} f\left(\varepsilon_{-}^{*}\right)\right]\right\} \\
& H_{B_{1}^{*}}^{\prime}=1+\rho-0.5(1+r)\left[\int_{\varepsilon_{+}^{*}}^{\varepsilon_{0}} f(\varepsilon) d \varepsilon+\int_{\varepsilon_{-}^{*}}^{\varepsilon_{0}} f(\varepsilon) d \varepsilon-\frac{\mu}{\chi Y^{*}}\left\{f\left(\varepsilon_{+}^{*}\right)+f\left(\varepsilon_{-}^{*}\right)\right\}\right]
\end{aligned}
$$

Gertler (1989) for a related analysis.

${ }^{9}$ We ignore the possibility of a bailout in case of default. See Aizenman and Marion (1999b) for a model where emerging-market governments are willing to bail out international creditors. In that case, uncertainty about the size of international reserves held by emerging markets for a possible bailout can also affect the supply of new loans. 
We assume that the emerging-market economies operate along the upward-sloping portion of the supply of international credit. ${ }^{10}$ Such would be the case if $-H_{r}{ }^{\prime}>0$ and $H_{B_{1}^{*}}{ }^{\prime}>0 .{ }^{11}$

Proposition 1: Greater uncertainty about debt overhang in emerging markets reduces the supply of international credit. Moreover, the supply of credit shifts in a nonlinear manner.

Applying (8), we find that for a given amount of new credit, $B_{1}^{*}$, increased uncertainty about the debt overhang shifts the supply of credit curve upwards by the amount:

${ }^{10}$ For a sufficiently low level of emerging-market debt, $\varepsilon^{*}=-\varepsilon_{0}$. In these circumstances, the critical condition for $d B_{1}^{*} / d r>0$ reduces to $\mu f\left(-\varepsilon_{0}\right) / \chi Y^{*}<1$, a condition that is satisfied for a low enough but positive enforcement cost, $\mu$. If $\mu f\left(-\varepsilon_{0}\right) / \chi Y^{*}>1$, the supply of credit is backward bending at interest rates marginally above the risk-free rate. In these circumstances it would be in the interest of emerging markets to prohibit borrowing. Consequently, we assume $\mu f\left(-\varepsilon_{0}\right) / \chi Y^{*}<1$, so that the supply-of-credit curve is upward sloping at relatively low interest rates. In general, the supply curve may contain a backward-bending section at high interest rates and external debt levels. In these circumstances, it would be in the interest of the borrowers to adopt policies that prevent them from reaching the backward-bending section of the supply curve since such a point entails lower welfare than the point where external borrowing is maximized. See Aizenman (1989) for further discussion.

"The supply of international credit (defined implicitly by (8)) and the demand for international credit jointly determine the equilibrium interest rate and level of credit. We focus our attention on the supply side. 


$$
\frac{d r}{\left.d \lambda\right|_{B_{1}^{*}}}=\frac{\bar{D}\left[\int_{\varepsilon_{-}^{*}}^{\varepsilon_{+}^{*}} f(\varepsilon) d \varepsilon-\frac{\mu}{\chi Y^{*}}\left\{f\left(\varepsilon_{+}^{*}\right)-f\left(\varepsilon_{-}^{*}\right)\right\}\right]}{B_{1}^{*}\left\{\left[\int_{\varepsilon_{+}^{*}}^{\varepsilon_{0}} f(\varepsilon) d \varepsilon-\frac{\mu}{\chi Y^{*}} f\left(\varepsilon_{+}^{*}\right)\right]+\left[\int_{\varepsilon_{-}^{*}}^{\varepsilon_{0}} f(\varepsilon) d \varepsilon-\frac{\mu}{\chi Y^{*}} f\left(\varepsilon_{-}^{*}\right)\right]\right\}}
$$

An important implication of (12) is that greater uncertainty about the debt overhang (a larger ג) has a non-linear effect on the supply of international credit. Greater uncertainty does not affect the supply of credit when the probability of default is zero. ${ }^{12}$ If the default probability is positive, however, greater uncertainty about the debt overhang reduces the supply of credit.

Proposition 2: . The greater the uncertainty about debt overhang, the more a given increase in uncertainty reduces the supply of credit. The greater the expected debt overhang, the more a given increase in uncertainty about debt overhang reduces the supply of credit.

We can rewrite (12) as:

$$
\frac{d r}{\left.d \lambda\right|_{B_{1}^{*}}}=\frac{2 \lambda(\bar{D})^{2}}{\chi Y^{*} B_{1}^{*}} \frac{f(\tilde{\varepsilon})-f^{*}(\widehat{\varepsilon}) \frac{\mu}{\chi Y^{*}}}{\left[\int_{\varepsilon_{+}^{*}}^{\varepsilon_{0}} f(\varepsilon) d \varepsilon-\frac{\mu}{\chi Y^{*}} f\left(\varepsilon_{+}^{*}\right)\right]+\left[\int_{\varepsilon_{-}^{*}}^{\varepsilon_{0}} f(\varepsilon) d \varepsilon-\frac{\mu}{\chi Y^{*}} f\left(\varepsilon_{-}^{*}\right)\right]}
$$

${ }^{12}$ In this case $\varepsilon_{+}^{*}=\varepsilon_{-}^{*}=-\varepsilon_{0}$, and $\frac{d r}{\left.d \lambda\right|_{B_{1}^{*}}}=0$. 
where $\tilde{\varepsilon} ; \bar{\varepsilon}$ are defined by the 'mid points' in the segment $\left[\varepsilon_{-}^{*}, \varepsilon_{+}^{*}\right]$, with

$f(\tilde{\varepsilon})=\frac{\int_{\varepsilon_{-}^{*}}^{\varepsilon_{+}^{*}} f(\varepsilon) d \varepsilon}{\varepsilon_{+}^{*}-\varepsilon_{-}^{*}} ; \quad f^{\prime}(\bar{\varepsilon})=\frac{f\left(\varepsilon_{+}^{*}\right)-f\left(\varepsilon_{-}^{*}\right)}{\varepsilon_{+}^{*}-\varepsilon_{-}^{*}}$ We maintain the assumption that the monitoring and enforcement cost $(\mu)$ is relatively small, so that $f(\tilde{\varepsilon})-f^{\prime}(\bar{\varepsilon}) \mu / \chi Y^{*}>0$.

Equation (13) reveals that when there is a chance of default, increased uncertainty about the debt overhang reduces the supply of credit in proportion to the product of the expected debt overhang $(\bar{D})$ and the initial degree of uncertainty $(\lambda)$. Consequently, the greater the expected debt overhang or the initial degree of uncertainty, the greater is the impact additional uncertainty has on the supply of credit. ${ }^{13}$

One can also verify that bad news about the expected level of outstanding debt $(d \bar{D}>0)$ reduces the supply of new credit $\left(d r /\left.d \bar{D}\right|_{B_{1}^{*}}>0\right)$. Figures 1-4 suggest that the financial crisis increased both the expected level of outstanding debt and the uncertainty about its actual size. Our model shows that uncertainty magnifies the reduction in credit induced by the level effect, and does so in a non-linear way.

\section{The disappearance of markets}

At the onset of the Asian financial crisis, the international credit market for these emerging markets collapsed. Countries that presumed they could access the international credit market learned the hard way that when credit is desperately needed, the market may go dry.

13 We can obtain the same results by modeling investment in period one that provides a random return in period two, since a low return is analogous to low productivity. 
This phenomenon can be explained in several ways. ${ }^{14}$ In terms of our model, if the crisis increases uncertainty about the debt overhang - or about other relevant factors affecting repayment-- the shift in the supply of funds may be abrupt enough to dry up the market. Such will be the case, for example, if the expected debt overhang or the uncertainty about its level is larger than the one anticipated by the a priori distribution, so that the revised supply of funds is backward bending at $B_{1}^{*}=0$.

There is an alternative and more general explanation, however. It is well known that agents exhibit home bias in their asset holdings. ${ }^{15}$ The unwillingness to supply new credit to emerging markets during a crisis may be viewed as a strengthening of the home-bias phenomenon. If one uses the capital asset-pricing model (CAPM) as the benchmark for explaining portfolio choice, the complete shift to home assets during a crisis is a puzzle since the CAPM predicts continued diversification. However, if portfolio choice is derived from a generalized expected utility framework with first-order risk aversion, the risk premium needed to maintain

${ }^{14}$ Radelet and Sachs (1998) and Chang and Velasco (1998a, 1998b) attribute the phenomenon to an investor panic, but without addressing the origin of the panic. Caballero and Krishnamurthy (1998) suggest it may be due to the real or perceived inadequacy of international collateral stemming from microeconomic contractual problems. Calvo (1999) hypothesizes that poorly informed investors may misread a shift out of emerging-market assets by liquidity-constrained informed traders as signaling low returns and this confusion may lead to a market collapse.

${ }^{15}$ For example, French and Poterba (1991) and Tesar and Werner (1992) note that $94 \%$ of US investor wealth is held in domestic equity, much more than the optimal share predicted by the conventional capital asset-pricing model (CAPM). See Lewis (1995) and Obstfeld and Rogoff (1996) for comprehensive overviews of the home-bias puzzle and existing interpretations within the context of the CAPM. 
international diversification is much larger. A small increase in uncertainty can eliminate the desire to diversify internationally, making investors unwilling to supply new international credits or roll over existing credits. Consequently, the disappearance of the market during a crisis may be the rule, rather than the exception. If this is the case, the potential benefits of liquidity and the proper maturity structure on debt are much larger than those predicted using the conventional CAPM framework.

We can formalize the argument by using a generalized expected utility (GEU) framework to describe preferences. We focus on a simple version of GEU that is a one-parameter extension of the standard (Savage ,1954) neoclassical expected utility model. In this version, agents attach greater weight to utility derived from "bad" outcomes than from "good" outcomes. ${ }^{16} \mathrm{~A}$ consequence of this weighting pattern is that the agents exhibits downside risk aversion and require a substantial risk premium to diversify internationally. ${ }^{17}$

Preferences are summarized by $[u(x), \gamma]$, where $\mathrm{u}$ is a conventional utility function describing the utility of consuming $\mathrm{x},\left[u^{\prime}>0, u^{\prime \prime}<0\right]$, and $1 \geq \gamma \geq 0$ is a parameter that measures the weighting of a high-ranked outcome relative to a low-ranked one. This weighting is obtained by replacing the probability weight $p_{i}$ attached to utility $u\left(x_{i}\right)$ in the standard expected utility framework with a modified weight, defined by a proper transformation of $p^{\gamma}$.

${ }^{16}$ The asymmetric evaluation of gains and losses may also be the result of the incentives facing portfolio managers who understand that their loss from underperforming the market is more costly than their gain from outperforming it.

${ }^{17}$ Similar results may be produced by other versions of generalized expected utility. See Segal and Spivak (1990) and Epstein (1992). 
Suppose that with probability $\alpha$ the agent receives income $x_{1}$, and with probability $(1-\alpha)$ income $x_{2}$, where $x_{1}>x_{2}$. The generalized expected utility $V(\gamma)$ is defined by ${ }^{18}$ :

$$
V(\gamma)=\left[1-(1-\alpha)^{\gamma}\right] u\left(x_{1}\right)+(1-\alpha)^{\gamma} u\left(x_{2}\right)
$$

Alternatively, $V(\gamma)=\alpha\left[1-\frac{1-\alpha}{\alpha} \omega\right] u\left(x_{1}\right)+(1-\alpha)[1+\omega] u\left(x_{2}\right)$, where $\omega=(1-\alpha)^{\gamma-1}-1$

For $\gamma=1, V$ is identical to the conventional expected utility. In this case, good and bad states of nature are treated symmetrically when $u\left(x_{i}\right)$ is weighted by the probability of its occurrence. For values of $\gamma$ less than one, the agent attaches an extra weight of $(1-\alpha) \omega$ to the "bad" outcome, and attaches a lesser weight of $(1-\alpha) \omega$ to the "good" outcome.

We focus now on a simple example of allocating initial wealth among 3 assets - a risk-free asset and risky domestic and foreign assets. The safe asset offers a real yield of $r_{0}$. The risky domestic and foreign assets offer random yields of $r ; r^{*}$, respectively. The realized yield for each risky asset may be high or low, depending on the state of nature. We denote the corresponding states of nature by $h$ and $l$ for the home asset and by $h^{*}$ and $l^{*}$ for the foreign one. The realized returns are given by

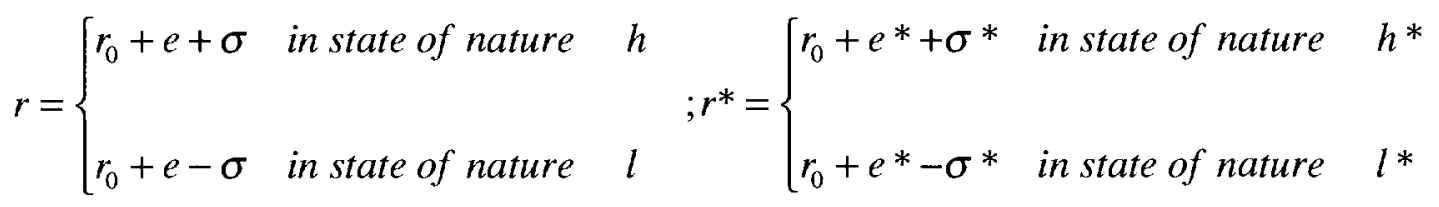

${ }^{18}$ The formulation in (14) is based on Yaari (1987). 
where $e, e^{*}$ denote the expected excess yields attached to the risky domestic and foreign assets, respectively, relative to the yield of the safe asset, and $\sigma, \sigma^{*}$ denote the standard deviations of the

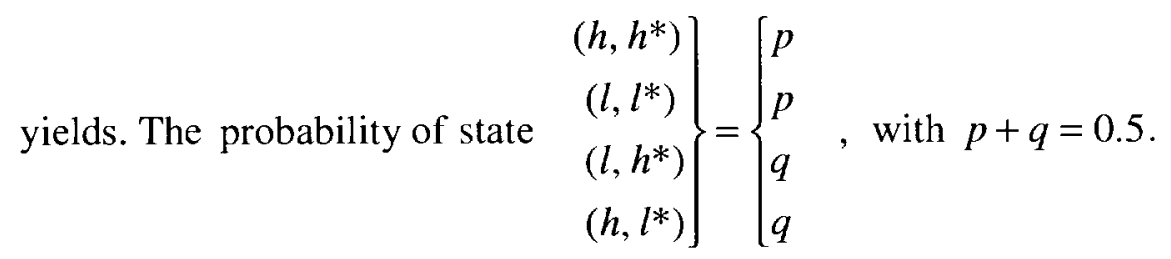
The correlation between the returns of the two risky assets is $\rho=4 p-1$.

The agent allocates fractions $\mathrm{x}$ and $\mathrm{x}^{*}$ of his initial wealth to the risky domestic and foreign asset, respectively. In financial autarky, $x^{*}=0$. International diversification is beneficial if, in the autarky equilibrium, $\frac{\partial V}{\partial x^{*}} \mid x=\tilde{x}>0$, where $\tilde{\mathrm{x}}$ denotes the optimal share of the risky domestic asset in financial autarky. It can be shown that with financial openness, the demand for the foreign asset is positive iff

$$
\begin{gathered}
\tau^{*}>\frac{(2 p)^{\gamma}-(p)^{\gamma}+(1-p)^{\gamma}-1}{1-(0.5)^{\gamma}}+\tau \frac{(2 p)^{\gamma}\left[1-(0.5)^{\gamma}\right]+(0.5)^{\gamma}-(1-p)^{\gamma}}{1-(0.5)^{\gamma}} \\
\tau=\frac{e}{\sigma} ; \tau^{*}=\frac{e^{*}}{\sigma^{*}}
\end{gathered}
$$

In (15), $\tau$ and $\tau^{*}$ are the normalized premiums on the risky domestic and foreign assets, respectively, where the normalization is obtained by dividing the premium by standard deviation of the yield. ${ }^{19}$

\footnotetext{
${ }^{19}$ In order to obtain (15), we use the specification for generalized utility in (14) and our assumptions about the properties of asset returns to infer that expected utility is:
} 
With the standard expected utility framework, $\gamma=1$ and $(15)$ is reduced to $\frac{\tau^{*}}{\tau}>\rho$. Hence, the risky foreign asset is demanded if its normalized premium exceeds the product of the correlation between returns and the normalized premium of the risky domestic asset. This condition is met trivially if the correlation is zero (or negative). For a positive correlation, an agent maximizing a conventional expected utility tends to diversify as long as the correlation among yields is not too close to one.

This result does not hold for an agent that demands a first-order risk premium, however. As long as the correlation between returns is positive, first-order risk aversion increases the normalized foreign premium needed for diversification. This result follows from the observation that the right-hand side of (15) depends negatively on $\gamma$.

Figure 5 plots the dependency of the foreign premium (the RHS of (15)) on $\gamma$ for the case where the normalized premium on the risky domestic asset is one-half [i.e., $\tau=\frac{e}{\sigma}=0.5$ ] and the correlation between returns on the two risky assets can be either zero or 0.5 . Points above

$$
\begin{aligned}
& V= \begin{cases}{\left[\begin{array}{l}
\left(1-[2 q+p]^{\gamma}\right) u\left(h, h^{*}\right)+\left([2 q+p]^{\gamma}-[q+p]^{\gamma}\right) u\left(h, l^{*}\right)+ \\
\left([q+p]^{\gamma}-[p]^{\gamma}\right) u\left(l, h^{*}\right)+[p]^{\gamma} u\left(l, l^{*}\right)
\end{array}\right]} & \text { if } x \sigma>x^{*} \sigma * \\
{\left[\begin{array}{l}
\left(1-[2 q+p]^{\gamma}\right) u\left(h, h^{*}\right)+\left([2 q+p]^{\gamma}-[q+p]^{\gamma}\right) u\left(l, h^{*}\right)+ \\
\left([q+p]^{\gamma}-[p]^{\gamma}\right) u\left(h, l^{*}\right)+[p]^{\gamma} u\left(l, l^{*}\right)
\end{array}\right]} & \text { if } x \sigma \leq x * \sigma *\end{cases} \\
& u\left(h, h^{*}\right)=u\left[1+r_{0}+x(e+\sigma)+x *\left(e^{*}+\sigma^{*}\right)\right] ; \quad u\left(l, l^{*}\right)=u\left[1+r_{0}+x(e-\sigma)+x^{*}\left(e^{*}-\sigma^{*}\right)\right] ; \\
& \text { where } u\left(h, l^{*}\right)=u\left[1+r_{0}+x(e+\sigma)+x^{*}\left(e^{*}-\sigma^{*}\right)\right] ; \quad u\left(l, h^{*}\right)=u\left[1+r_{0}+x(e-\sigma)+x *\left(e^{*}+\sigma^{*}\right)\right] \text {; }
\end{aligned}
$$

We then use (A) and the first-order condition for the optimal portfolio in autarky to obtain (15), writing the condition in terms of normalized returns. Aizenman (1999) and Aizenman and Marion (1999a) use a generalized utility framework that relies on a second-order approximation to derive results. Here we find the exact analytical condition leading to a positive demand for foreign assets in autarky. 
the curve [area D] define the range where the demand for the foreign asset is positive. Notice that if the correlation among returns is zero, the CAPM (with $\gamma=1$ ) predicts that the agent will always demand a foreign asset offering a positive return.

The case for diversification is much weaker if the agent exhibits first-order risk aversion, with $\gamma<1 .^{20}$ Similar results hold if the correlation is positive, although with positive correlation the foreign normalized excess return must be positive to induce diversification even in the CAPM model.

The implication of this analysis is that a moderate increase in the risk of the foreign asset will terminate diversification if agents are first-order risk averse. Using Figure 5, suppose that $\rho=0.5, \gamma=0.75$, and that initially the normalized excess return of the foreign assets is $\tau^{*}=0.4$. In these circumstances, we will observe diversification, as the point corresponding to the initial equilibrium is in the $\mathrm{D}$ range above the zero-diversification curve. An exogenous drop of $\tau^{*}$ from 0.4 to 0.3 will end diversification, causing the market for the foreign assets to dry up. The drop in $\tau^{*}$ may be the outcome of many combinations of changing $\mathrm{e}^{*}$ and $\sigma^{*}$. For example, suppose that initially $\mathrm{e}=0.05, \sigma=0.10, \mathrm{e}^{*}=0.06$ and $\sigma^{*}=0.15$ (so that $\tau=0.5$ and $\tau^{*}=0.4$ ). A rise in $\sigma^{*}$ to 0.20 will reduce $\tau^{*}$ to 0.3 , terminating diversification. Alternatively, a drop in $\mathrm{e}^{*}$ to 0.045

\footnotetext{
20) In the generalized expected utility specified by (14), the term $\omega=\left(0.5^{\gamma-1}-1\right)$ measures the first-order risk aversion exhibited by agents. Loss aversion, defined as the ratio of the marginal utility of a loss to the marginal utility of a gain, is $[1+\omega] /[1-\omega]$. Empirical estimates of loss aversion are typically in the neighborhood of two, suggesting that $\gamma \cong 0.74$ if preferences conform to the generalized utility framework. See Tversky and Kahneman (1991) and
} 
will induce the same change in $\tau^{*}$ and eliminate diversification. If instead agents behave according to the CAPM (where $\gamma=1$ ), the same decline in the normalized foreign excess return will not end diversification, only reduce it.

\section{Conclusion}

We have shown how a collapse of the international credit market can occur when the perceived risk of lending to emerging markets increases, even moderately. Any number of factors can alter risk perceptions. We focus on one factor that was important for Thailand, Korea, and other emerging markets in late 1997. This factor was a growing awareness on the part of investors that the uncertainty about emerging-market external debt was greater than previously thought. Once the market updated its risk assessment, the reduction of international credit to these countries-- or even the collapse of the market altogether - can be explained by models of sovereign risk or models that reveal the "home bias" investment patterns of agents with firstorder risk aversion.

For expositional simplicity, we have illustrated the reduction and collapse of international credit in two separate models. The first model is one of sovereign risk, extended to account for uncertainty about debt overhang. There we maintain the conventional assumptions about risk preferences, such as the risk-neutrality of foreign lenders. The second model describes the portfolio diversification patterns of agents who are first-order risk averse. We use it to derive the exact analytical condition that terminates international diversification, causing a market collapse.

Kahneman, Knetsch and Thaler (1990). See Harless and Camerer (1994) for an empirical assessment of the generalized expected utility approach. 
We have left for future work the ambitious task of integrating these two models in order to study sovereign risk when all agents are first-order risk averse.

While we have focused on the role of debt overhang in altering risk perceptions about some of the Asian economies, we believe that other factors also could have played a role. For example, if the market changed its perception about the growth prospects of the Far East from the upbeat view of the 'East Asian Miracle' to the more somber assessment of Young (1992) and Krugman (1994), this revision in perceived risk could have contributed to the collapse of the international credit market. 


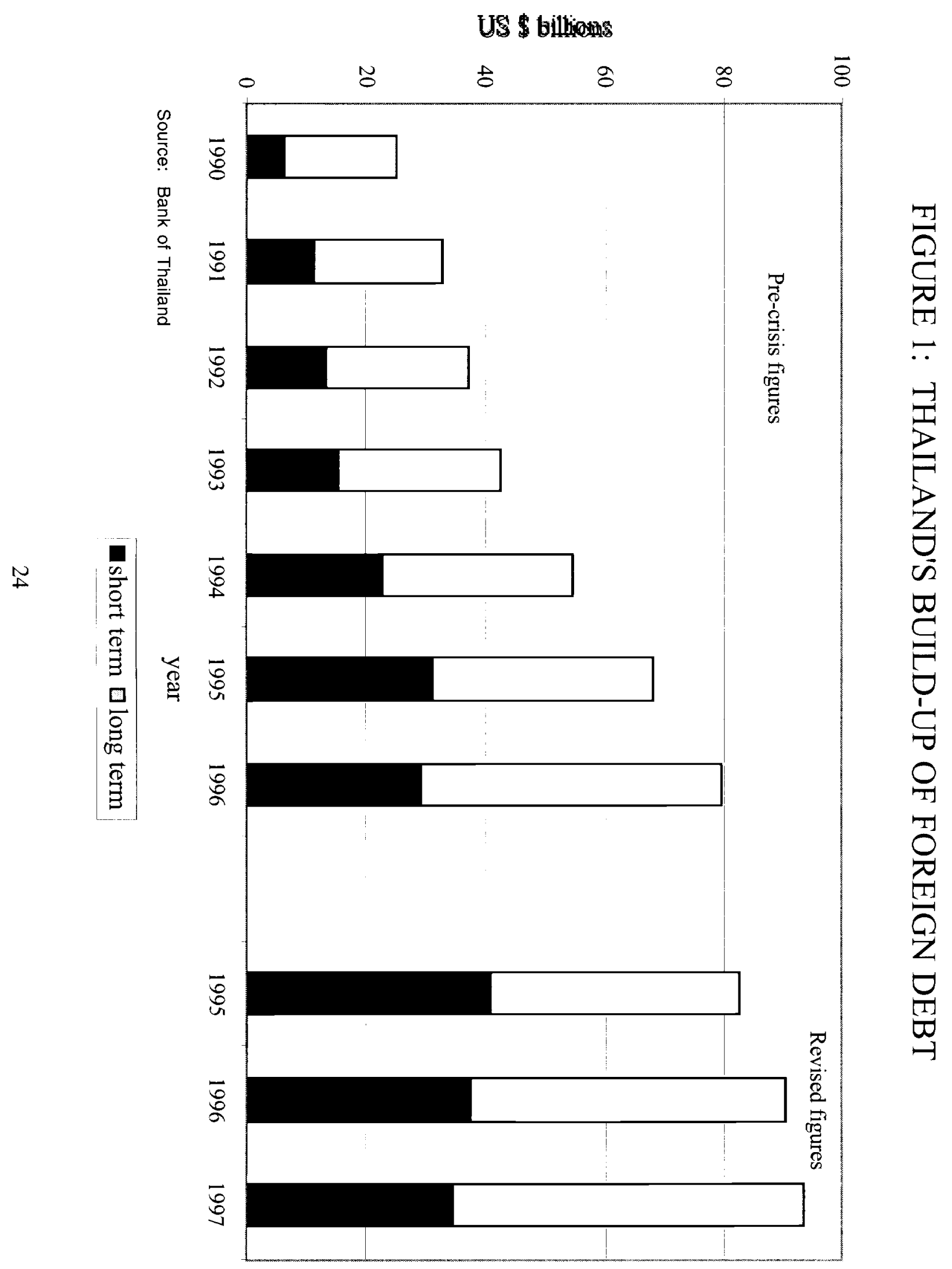




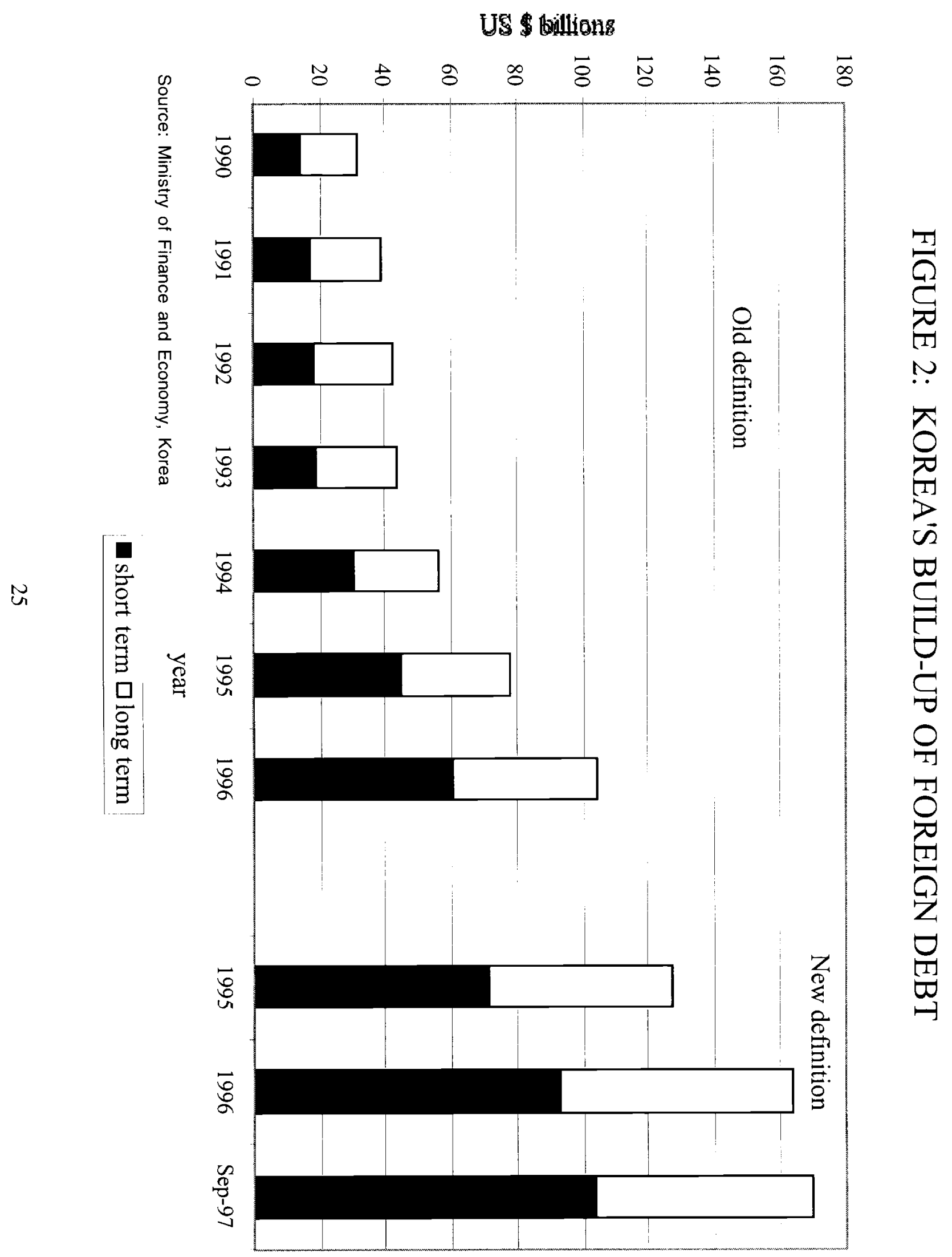




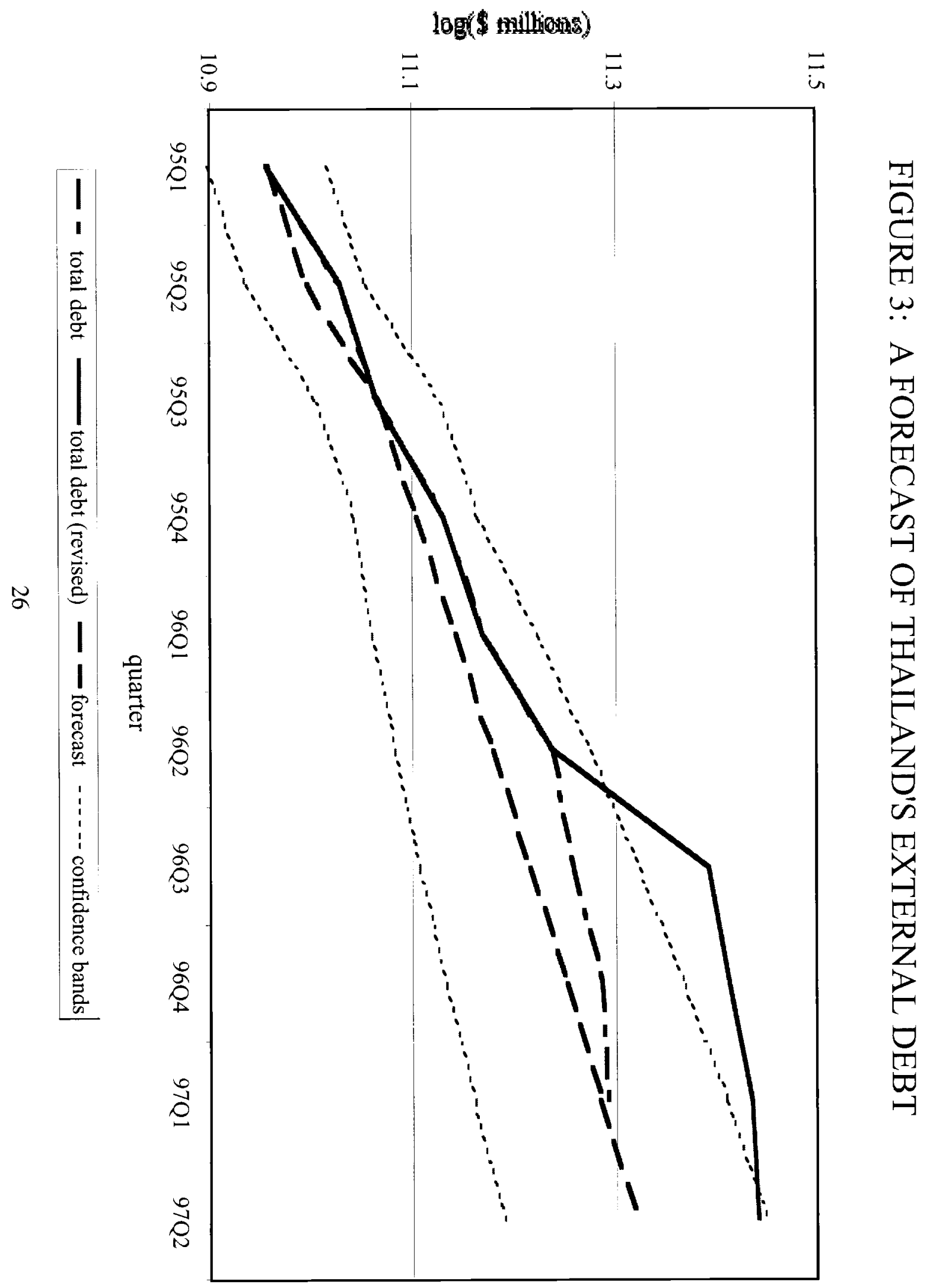




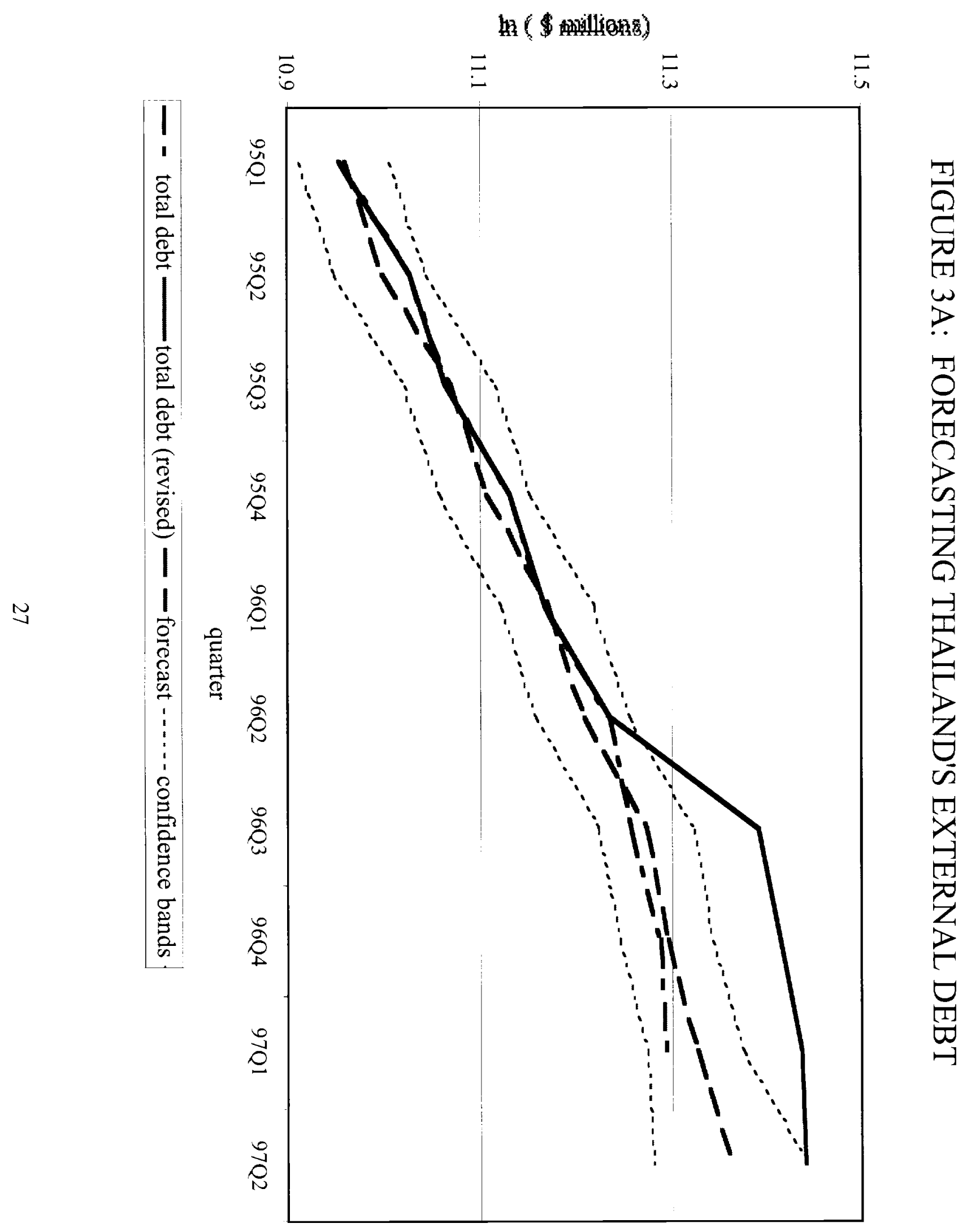




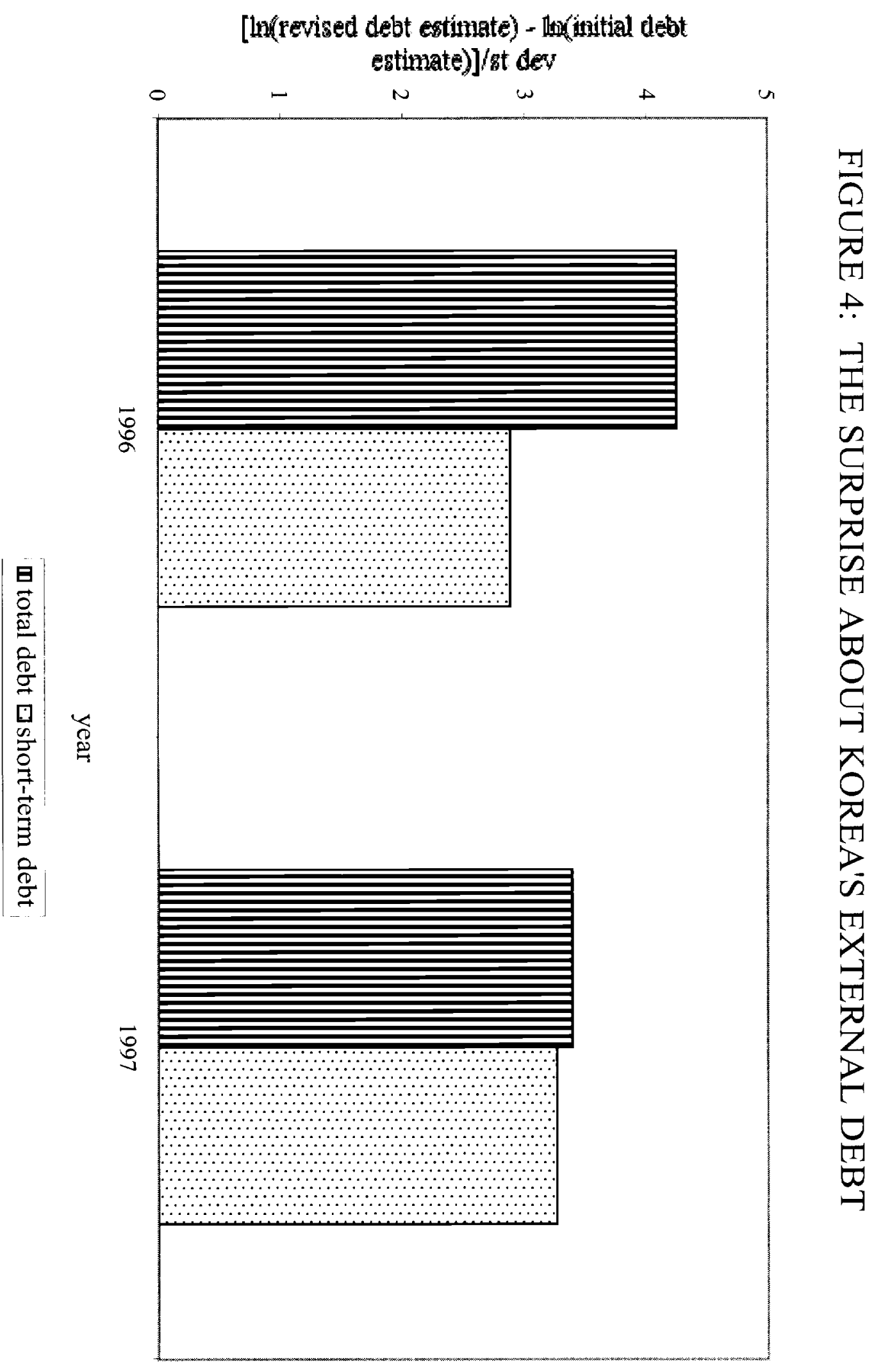



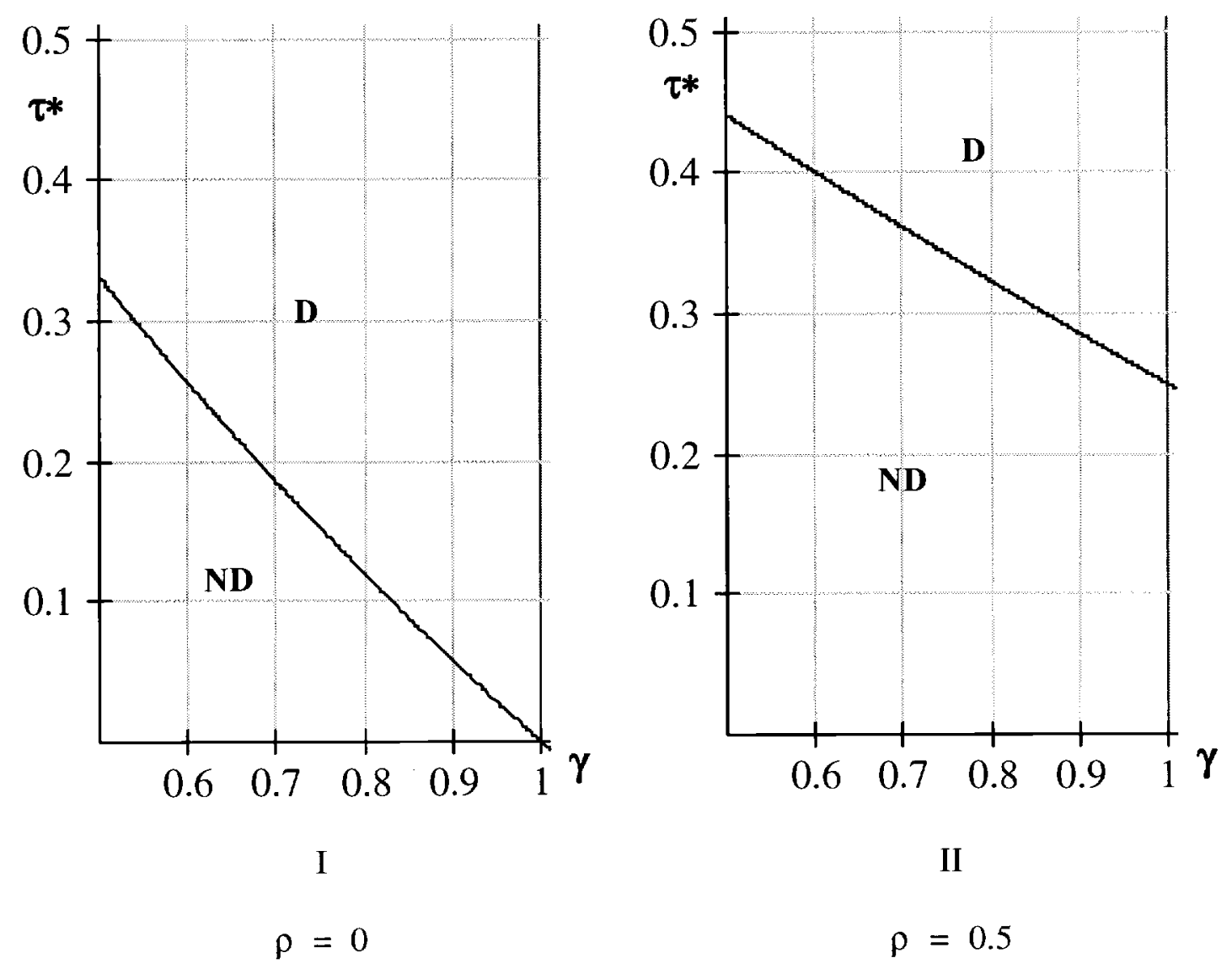

Drawn for $\tau=0.5$

FIGURE 5: The Foreign Premium Required for Diversification 


\section{References}

Adams, Charles, D. Mathieson, G. Schinasi, and B. Chadha, (1998), International Capital

Markets: Developments, Prospects, and Key Policy Issues, International Monetary Fund, September.

Aizenman, Joshua (1989) "Country Risk, Incomplete Information and Taxes on International Borrowing," Economic Journal 99, 147-161.

(1999), "International Portfolio Diversification with Generalized Expected

Utility Preferences," Canadian Journal of Economics 32, No. 4, 1010-1023.

Aizenman, Joshua and N. Marion (1999a) "Volatility and Investment: Interpreting Evidence from

Developing Countries“", Economica 66, 157-79.

(1999b) "Reserve Uncertainty and the Supply of International

Credit," Dartmouth Working paper, June.

Bernanke, Ben and M. Gertler (1989), “Agency Costs, Net Worth, and Business Fluctuations," American Economic Review 79, 14-31.

Boyd, J.H. and B.D. Smith (1994), "How Good are Standard Debt Contracts? Stochastic versus

Nonstochastic Monitoring in a Costly State Verification Environment," Journal of Business $67,539-561$.

Bulow, Jeremy and K. Rogoff (1989), "A Constant Recontracting Model of Sovereign Debt," Journal of Political Economy; 97(1), 155-78.

Caballero, Ricardo and Arvind Krishnamurthy (1998), "Emerging Market Crises: an Asset

Markets Perspective," NBER Working Paper No. 6843, December.

Calvo, Guillermo (1999). "Contagion in Emerging Markets: When Wall Street is a Carrier," World

Bank/Universidat Torcuato Di Tella Conference on Integration and Contagion, June 17-18, 1999.

Chang, Roberto and Andres Velasco (1998a), "Financial Crises in Emerging Markets: A Canonical Model," NBER Working Paper No. 6606, June. 
No. 6796, November.

Economist (1997), "Feeling the Heat," May 17, p. 82.

Epstein, L. G. (1992) "Behavior Under Risk: Recent Developments in Theory and Applications," Chapter 1 in Advances in economic theory: Sixth World Congress., Volume 1, LaffontJean-Jacques, ed. (Cambridge University Press), 1-63.

French, K. and J. Poterba (1991) "International Diversification and International Equity Markets," American Economic Review, 222-226.

Harless, D. W. and C. Camerer (1994), "The Predictive Utility of Generalized Expected Utility Theories," Econometrica 62(6), November, 1251-89.

Kahneman, D., J. Knetsch, and R. Thaler (1990), "Experimental Tests of the Endowment Effect and the Coase Theorem," Journal of Political Economy 98, 1325-48.

Krugman, Paul (1994), “The Myth of Asia's Miracle, a Cautionary Fable,” Foreign Affairs, November/December.

Lewis, Karen (1995) "Puzzles in International Financial Markets," Chapter 37 in G. Grossman and K. Rogoff, editors, Handbook of International Economics, Volume III.

Mathieson, Don (forthcoming), "Comment," in Peter Isard, Assaf Razin and Andrew Rose (editors), International Finance in Turmoil: Essays in Honor of Robert F. Flood, Washington and Boston: IMF and Kluwer Academic Publishers.

Obstfeld, M. and K. Rogoff (1996) Foundations of International Macroeconomics, MIT Press.

Organization for Economic Co-Operation and Development (1998), Economic Survey: Korea, Paris: OECD Publications.

Park, Daekeun and C. Rhee (1998). "Currency Crisis in Korea: How Has It Been Aggravated?" mimeo, Seoul National University, December.

Radelet, Steven and Jeff Sachs 91998). “The East Asian Financial Crisis: Diagnosis, Remedies, Prospects," Brookings Papers on Economic Activity, Volume 1. 
Savage, L. J. (1954), Foundations of Statistics, New York: John Wiley.

Segal, U. and A. Spivak (1990) "First-Order versus Second-order Risk Aversion,"Journal of Economic Theory, Vol. 51, 111-25.

Tesar, L. L. and I. M. Warner (1995) "Home Bias and High Turnover," Journal of International Money and Finance; 14 (4), 467-92.

Tversky, A. and D. Kahneman (1991), "Loss Aversion and Riskless Choice: A Reference Dependence Model," Quarterly Journal of Economics 106, 1039-61.

Townsend, R.M. (1979), "Optimal Contracts and Competitive Markets with Costly State Verification, Journal of Economic Theory 21, 265-293.

Yaari, M.E. (1987), “The Dual Theory of Choice under Risk,” Econometrica 55, 95-115.

Young. A. (1992), "A Tale of Two Cities: Factor Accumulation and Technical Change in Hong Kong and Singapore," in Blanchard O. and S. Fischer, eds., . NBER Macroeconomics Annual992.. Cambridge and London: MIT Press, 13-54. 
To order any of these papers in hard copy, see instructions at the end of this list. To subscribe to all NBER Working Papers or the papers in a single area, see instructions inside the back cover.

Number

$\underline{\text { Author(s) }}$

7337

7338

7339

7340

7341

7342

7344

7345

7346

7347

7348

7349

7350

7351
Kathryn M. Dominguez

Jeffrey A. Frankel

Axel Börsch-Supan

Hylke Vandenbussche Jozef Konings

Linda Springael

Robert F. Engle

Simone Manganelli

David C. King

Richard J. Zeckhauser

Christina Paxson

Jane Waldfogel

Michael Hout

Harvey S. Rosen

Jean O. Lanjouw

Mark Schankerman

Geert Bekaert

Steven R. Grenadier

Thomas N. Hubbard

Jonathan Gruber

Edward P. Lazear

Tamim Bayoumi

Taizo Motonishi

Hiroshi Yoshikawa $\underline{\text { Title }}$

Date

The Market Microstructure of Central Bank Intervention 9/99

No Single Currency Regime is Right for all Countries $\quad 9 / 99$ or at All Times

Incentive Effects of Social Security Under an Uncertain $\quad 9 / 99$ Disability Option

Import Diversion under European Antidumping Policy $\quad 9 / 99$

CAViaR: Conditional Value at Risk By Quantile

$9 / 99$

Regression

Congressional Vote Options

$9 / 99$

Work, Welfare, and Child Maltreatment

$9 / 99$

Self-Employment, Family Background, and Race

The Quality of Ideas: Measuring Innovation with 9/99 Multiple Indicators

Stock and Bond Pricing in an Affine Economy

$9 / 99$

How Wide Is the Scope of Hold-Up-Based Theories? 9/99 Contractual Form and Market Thickness in Trucking The Wealth of the Unemployed: Adequacy and Implications for Unemployment Insurance

Educational Production

$9 / 99$

The Morning After: Explaining the Slowdown in $9 / 99$ Japanese Growth in the 1990s

Causes of the Long Stagnation of Japan during the $9 / 99$

You can download these and other papers at the NBER Web site:

Free searchable abstracts are also available at the site. 
To order any of these papers in hard copy, see instructions at the end of this list. To subscribe to all NBER Working Papers or the papers in a single area, see instructions inside the back cover.

\begin{tabular}{|c|c|}
\hline Number & Author(s) \\
\hline 7352 & $\begin{array}{l}\text { Daron Acemoglu } \\
\text { Robert Shimer }\end{array}$ \\
\hline 7353 & $\begin{array}{l}\text { Jeff Grogger } \\
\text { Charles Michalopoulos }\end{array}$ \\
\hline 7354 & Roberto Rigobon \\
\hline 7355 & $\begin{array}{l}\text { Ricardo J. Caballero } \\
\text { Mohamad L. Hammour }\end{array}$ \\
\hline 7356 & $\begin{array}{l}\text { Alec Ian Gershberg } \\
\text { Michael Grossman } \\
\text { Fred Goldman }\end{array}$ \\
\hline 7357 & Robert E. Lipsey \\
\hline 7358 & Vernon Henderson \\
\hline 7359 & $\begin{array}{l}\text { Iain Cockburn } \\
\text { Rebecca Henderson } \\
\text { Scott Stern }\end{array}$ \\
\hline 7360 & $\begin{array}{l}\text { Douglas Holtz-Eakin } \\
\text { John W. Phillips } \\
\text { Harvey S. Rosen }\end{array}$ \\
\hline 7361 & $\begin{array}{l}\text { Bong-Chan Kho } \\
\text { René M. Stulz }\end{array}$ \\
\hline 7362 & $\begin{array}{l}\text { Jagadeesh Gokhale } \\
\text { Laurence J. Kotlikoff }\end{array}$ \\
\hline 7363 & $\begin{array}{l}\text { Bruce D. Meyer } \\
\text { Dan T. Rosenbaum }\end{array}$ \\
\hline 7364 & $\begin{array}{l}\text { Dani Rodrik } \\
\text { Andrés Velasco }\end{array}$ \\
\hline 7365 & $\begin{array}{l}\text { Michael D. Bordo } \\
\text { Lars Jonung }\end{array}$ \\
\hline
\end{tabular}

Title

$\underline{\text { Date }}$

Productivity Gains From Unemployment Insurance $\quad 9 / 99$

Welfare Dynamics under Time Limits

$9 / 99$

On the Measurement of the International Propagation

9/99 of Shocks

The Cost of Recessions Revisited: A Reverse-

$9 / 99$

Liquidationist View

Competition and the Cost of Capital Revisited: Special $\quad 9 / 99$ Authorities and Underwriters in the Market for Taxexempt Hospital Bonds

Foreign Production by U.S. Firms and Parent Firm $\quad 9 / 99$ Employment

Marshall's Economies $9 / 99$

The Diffusion of Science-Driven Drug Discovery:

Organizational Change in Pharmaceutical Research

Estate Taxes, Life Insurance, and Small Business

$9 / 99$

Banks, the IMF, and the Asian Crisis

Social Security's Treatment of Postwar Americans:

$9 / 99$ How Bad Can It Get?

Welfare, the Earned Income Tax Credit, and the

Labor Supply of Single Mothers

Short-Term Capital Flows

The Future of EMU: What Does the History of Monetary Unions Tell Us?

You can download these and other papers at the NBER Web site:

www.nber.org

Free searchable abstracts are also available at the site. 
To order any of these papers in hard copy, see instructions at the end of this list. To subscribe to all NBER Working Papers or the papers in a single area, see instructions inside the back cover.

\begin{tabular}{|c|c|}
\hline Number & Author(s) \\
\hline 7366 & Emmanuel Saez \\
\hline 7367 & Emmanuel Saez \\
\hline 7368 & $\begin{array}{l}\text { Alan L. Gustman } \\
\text { Thomas L. Steinmeier }\end{array}$ \\
\hline 7369 & $\begin{array}{l}\text { Wolfgang Keller } \\
\text { Arik Levinson }\end{array}$ \\
\hline 7370 & $\begin{array}{l}\text { Michael Baker } \\
\text { Gary Solon }\end{array}$ \\
\hline 7371 & $\begin{array}{l}\text { Michael Baker } \\
\text { Nicole M. Fortin }\end{array}$ \\
\hline 7372 & $\begin{array}{l}\text { B. Douglas Bernheim } \\
\text { Lorenzo Forni } \\
\text { Jagadeesh Gokhale } \\
\text { Laurence J. Kotlikoff }\end{array}$ \\
\hline 7373 & $\begin{array}{l}\text { Paul A. David } \\
\text { Bronwyn H. Hall } \\
\text { Andrew A. Toole }\end{array}$ \\
\hline 7374 & $\begin{array}{l}\text { Peter Cappelli } \\
\text { David Neumark }\end{array}$ \\
\hline 7375 & Charles I. Jones \\
\hline 7376 & $\begin{array}{l}\text { Harrison Hong } \\
\text { Jeremy C. Stein }\end{array}$ \\
\hline 7377 & $\begin{array}{l}\text { George Chacko } \\
\text { Luis M. Viceira }\end{array}$ \\
\hline 7378 & $\begin{array}{l}\text { Bruce A. Blonigen } \\
\text { Stephen E. Haynes }\end{array}$ \\
\hline 7379 & Victor R. Fuchs \\
\hline
\end{tabular}

Title

Date

Do Taxpayers Bunch at Kink Points?

$9 / 99$

The Effect of Marginal Tax Rates on Income: A Panel 9/99 Study of 'Bracket Creep'

What People Don't Know About Their Pensions and Social Security: An Analysis Using Linked Data From The Health and Retirement Study

Environmental Compliance Costs and Foreign Direct $9 / 99$ Investment Inflows to U.S. States

Earnings Dynamics and Inequality among Canadian Men, 1976-1992: Evidence from Longitudinal Income Tax Records

Occupational Gender Composition and Wages in Canada: 9/99 1987-1988

The Adequacy of Life Insurance: Evidence from the $10 / 99$ Health and Retirement Survey

Is Public R\&D a Complement or Substitute for Private $10 / 99$ R\&D? A Review of the Econometric Evidence

Do "High Performance" Work Practices Improve $10 / 99$ Established-Level Outcomes?

Was an Industrial Revolution Inevitable?

Economic Growth Over the Very Long Run

Differences of Opinion, Rational Arbitrage and Market Crashes

Dynamic Consumption and Portfolio Choice with $10 / 99$ Stochastic Volatility in Incomplete Markets

Antidumping Investigators and the Pass-Through of $10 / 99$ Exchange rates and Antidumping Duties

The Future of Health Economics

You can download these and other papers at the NBER Web site:

www.nber.org

Free searchable abstracts are also available at the site. 
To order any of these papers in hard copy, see instructions at the end of this list. To subscribe to all NBER Working Papers or the papers in a single area, see instructions inside the back cover.

\begin{tabular}{|c|c|}
\hline Number & Author(s) \\
\hline 7380 & $\begin{array}{l}\text { Michael D. Hurd } \\
\text { James P. Smith }\end{array}$ \\
\hline 7381 & Olivia S. Mitchell \\
\hline 7382 & $\begin{array}{l}\text { Michael B. Devereux } \\
\text { Charles Engel } \\
\text { Cedric Tille }\end{array}$ \\
\hline 7383 & $\begin{array}{l}\text { Stephen L. Mehay } \\
\text { Rosalie Liccardo Pacula }\end{array}$ \\
\hline 7384 & $\begin{array}{l}\text { Michael Klein } \\
\text { Giovanni Olivei }\end{array}$ \\
\hline 7385 & $\begin{array}{l}\text { Jean Abraham } \\
\text { Ashish Arora } \\
\text { Martin Gaynor } \\
\text { Douglas Wholey }\end{array}$ \\
\hline 7386 & $\begin{array}{l}\text { Gerardo della Paolera } \\
\text { Alan M. Taylor }\end{array}$ \\
\hline 7387 & $\begin{array}{l}\text { Alberto Alesina } \\
\text { Stephen Danninger } \\
\text { Massimo V. Rostagno }\end{array}$ \\
\hline 7388 & $\begin{array}{l}\text { Oliver Hart } \\
\text { John Moore }\end{array}$ \\
\hline 7389 & $\begin{array}{l}\text { Joshua Aizenman } \\
\text { Nancy Marion }\end{array}$ \\
\hline
\end{tabular}

Title

Date

Anticipated and Actual Bequests

$10 / 99$

New Trends in Pension Benefit and

$10 / 99$

Retirement Provisions

Exchange Rate Pass-through and the Welfare

$10 / 99$

Effects of the Euro

The Effectiveness of Workplace Drug Prevention

$10 / 99$

Policies: Does 'Zero Tolerance' Work?

Capital Account Liberalization, Financial Depth and

Economic Growth

Enter at Your Own Risk: HMO Participation and

$10 / 99$

Enrollment in the Medicare Risk Market

Internal Versus External Convertibility and Developing- 10/99

Country Financial Crises: Lessons from the Argentine

Bank Bailout of the 1930's

Redistribution Through Public Employment: The Case $10 / 99$ of Italy

On the Design of Hierarchies: Coordination Versus $\quad 10 / 99$

Specialization

Uncertainty and the Disappearance of International

$10 / 99$

Credit

Copies of the above working papers can be obtained for $\$ 10.00$ per copy (plus $\$ 10.00$ per order for shipping for all locations outside the continental U.S.) to Working Papers, NBER, 1050 Massachusetts Avenue, Cambridge, MA 02138-5398. Pre-payment is required on all orders and may be made by check or credit card. Checks should be made payable to the NBER and must be in dollars drawn on a U.S. bank. If paying by credit card, include the cardholder's name, account number, and expiration date. For all orders, please be sure to include your return address and telephone number. Working papers may also be ordered by telephone (868-3900), fax (617-868-2742), or email (orders@nber.org).

You can download these and other papers at the NBER Web site:

www.nber.org

Free searchable abstracts are also available at the site. 